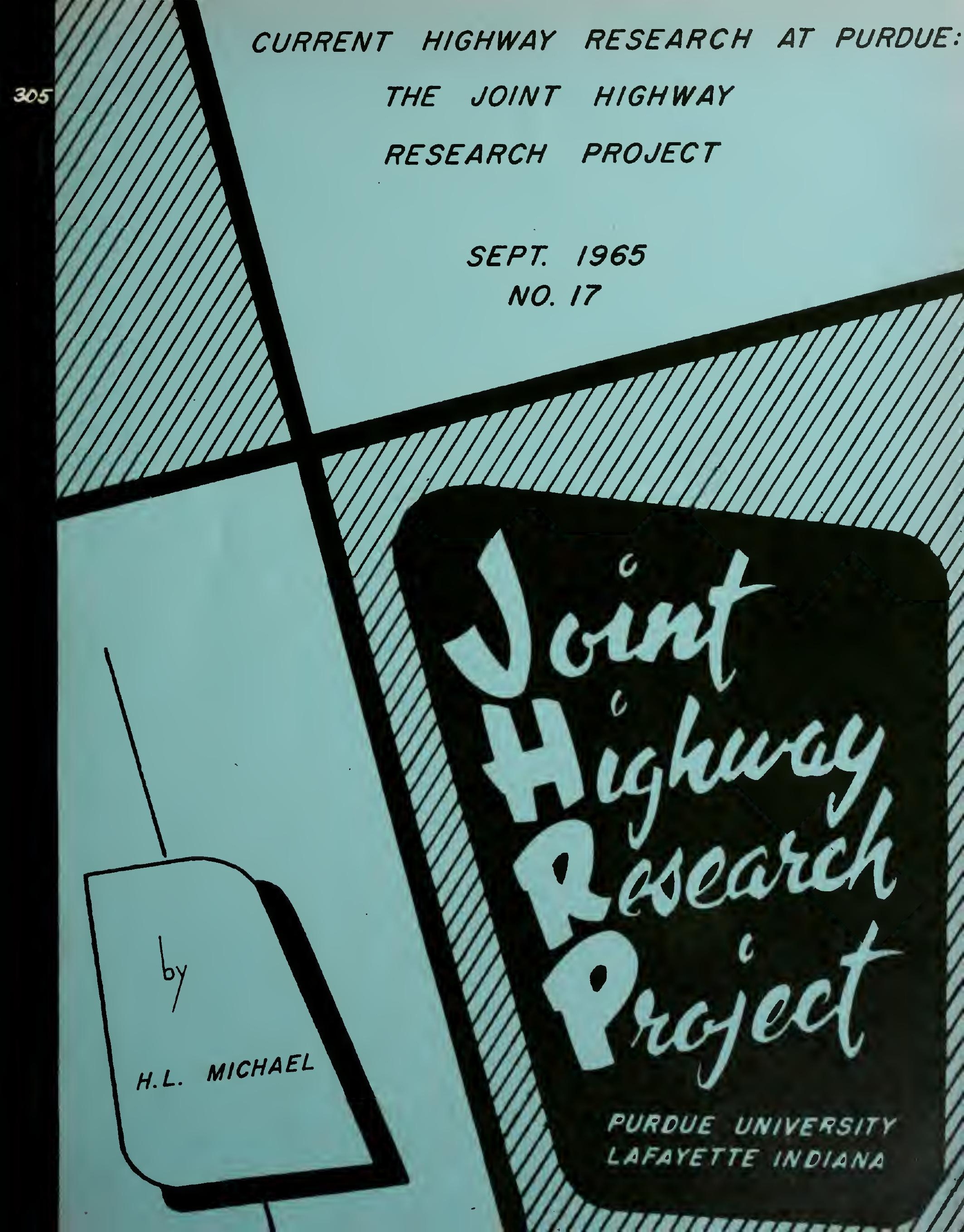


To:

G. A. Leonards, Director

Jolnt Highway Rezearch Project

September 24, 1965

Brow: H. L. Mchrel, Associate Director

File: 10-5-1

Joint Highway Research Project

The attached technical papar "Current Highway Research at Surdue: The Joint Highway Research Project" is a brfef aunary of the approximately 50 research projects active in the Broject In 1964-65. The paper presented at the Annual Purdus Road School in varch 1965 and is scheduled to be publiahed in the Proceedings. It has been prepared by Harold I. Michael, Assoclate Director.

The paper is presented to the Board for their information as well as for the record and for approval of publication in the Rond School Broceedings.

Respectuliy abnitred,

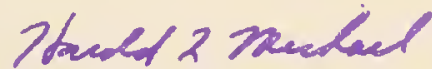

Barold lo. Mlchael, Secretary

Bus: $\mathrm{bc}$

Attachnent

Copy:

F. Io Ashbaucher

J. R. Cooper

J. W. Dehleur

W. L. Dolch

W. H. Goetz

W. Lo Grecco

F. H. Havey

F. S. H111

J. Meluagh11n
R.B. Meaderba 11

R. D。 Milee

J. C. Oppenlander

W. P. Privette

M. B. Scote

J. V. Saythe

F. W. Stubbs

B. B. Woods

B. Jo Yoder 
Techuicad Paper

CURREM HTGHAI RESEARCR AT PURDUR

THE JOIRT HIGWAP RESEARGE PROJEGT

by

Harold I. Michael.

Aseosiate Director

Joint Highway Research Project

F11e: 10-5-1

Purdue Univers1ty

Lafayetto, Ind Lane

Seprember 24, 1965 
Digitized by the Internet Archive in 2011 with funding from

LYRASIS members and Sloan Foundation; Indiana Department of Transportation 
CURREWT HICHWAY RESEARCH AIS PURDUE:

IUJE JOTNP HICHWAY RESEARCH PROJECT

The highway research program of the Joint Highwey Research Project at Purque University at any one time consists of 40 to 50 projects. These projects vary in size and complexity but typically a project will be performed by a prineipal investigator under the direction of an experlenced research engineer and wll be from one to three years in lengtb.

The selection of projects is one of the primary responsibilities of the Advisory Board of the Project and almost every Idea for a research project originates with a Board member or some member of the Indiena State Highway Comission. This is as it should be for one of the privrary purposes of the Jolnt BLghway Research Project is to provide solutions to problems of the Indians State HLginway Comission.

During this flscal year 1964-65, 51 research projects bave been active and as of the present date, March 1965, 43 highway research projects are active. It has been the practice each year at the research session of the Rogd School to report in some detail on two to four of the projects. Whis year only one of the current researches will be reported in detall and I will briefly discums the other 50 projects which have been or st111 are active this year.

The current research can be classifled Into ten areas and the research in each ares w1ll be discussed as a group. The first of the areas, in alphabetical order, is Almphoto Interpretation and Photogrametry. 


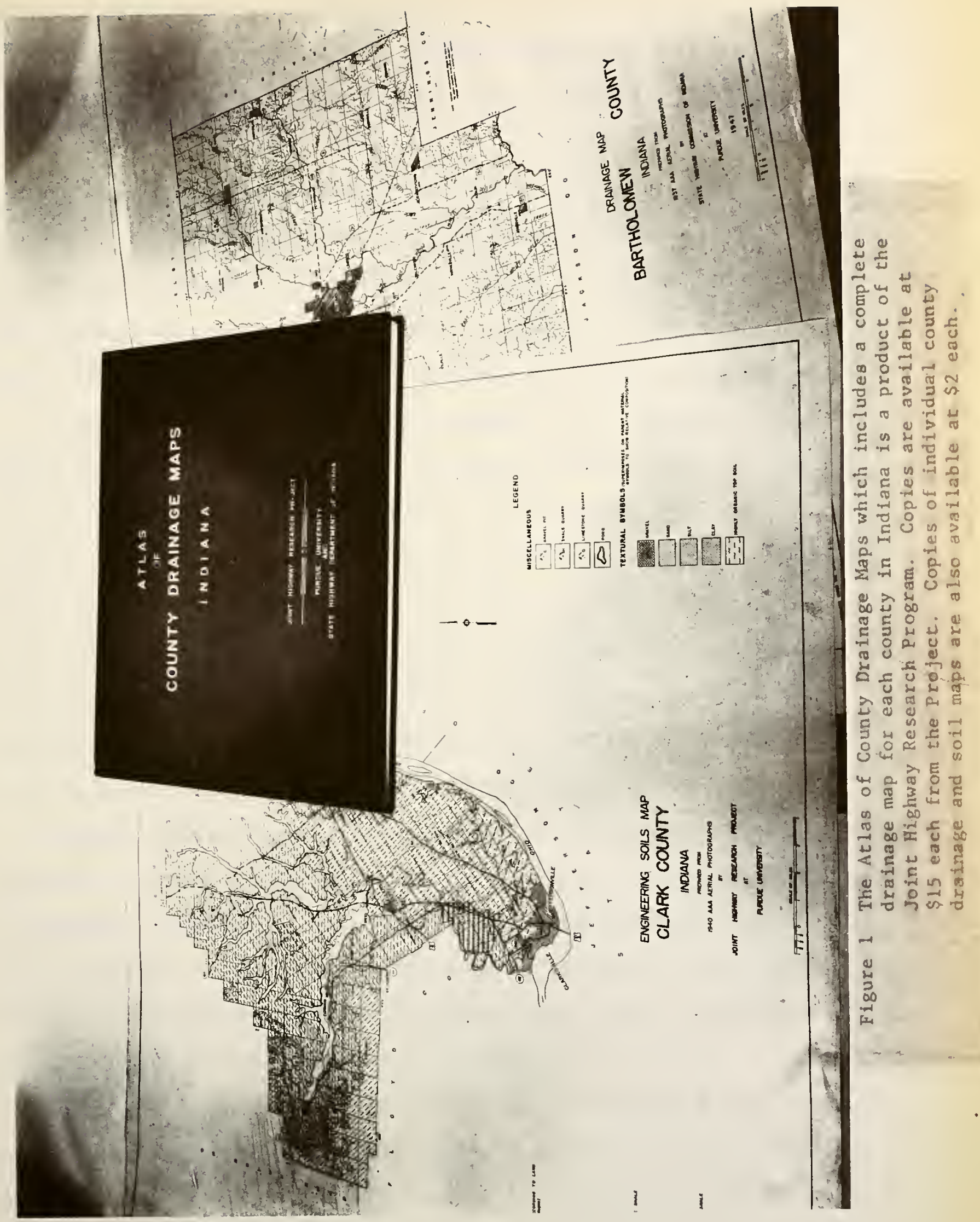




\section{Airnhoto Interporetation and Photogrametry.}

Perhaps the best lnown and most important activity of this area is the completed and widely known project which produced a drainage map for each county in the state. These maps are avallable in individual or Atlas form. Currently a state drainage map is in preparation with the material on each of the county maps being transferred to a state map. The map is complete except for flnal review and publication. When pubilished in a fer months, a complete dralnarge map of the state will be available for use in regional and state wide planning operations.

Of equal Importance to the drainage mapping is the englneering solis mapping of the state. These maps are also being prepared in county untts and maps for 35 of the Indiana counties are now avilable. Mhe more recent of these maps also include data from sample soll tests as a part of the map. Because two of the most Ingortant uses of these maps are in determining the location of a highwey improvement and in preparing a soil boring program, most of the effort of the past year in this area has been devoted to the preparation of soll strip maps of the corridors of the proposed routes of the yetato-be built interstate highways.

Another related project is investigeting the rellability of direct and Indirect methods of soll exploration to suggest the optimel propram of subsurface investigation for a highway improvement. The necesaary spacing and depth of soll borings and the use of information from soil tests by design engineers is being evaluated so that a soll test program can be developed wich is adequate and economical.

Another research study just getting underway will determine the extent to wich multisensor photography and imagery in the ultra violet, inirared and radar apectrum can be used to determine the engineering characteristfos 


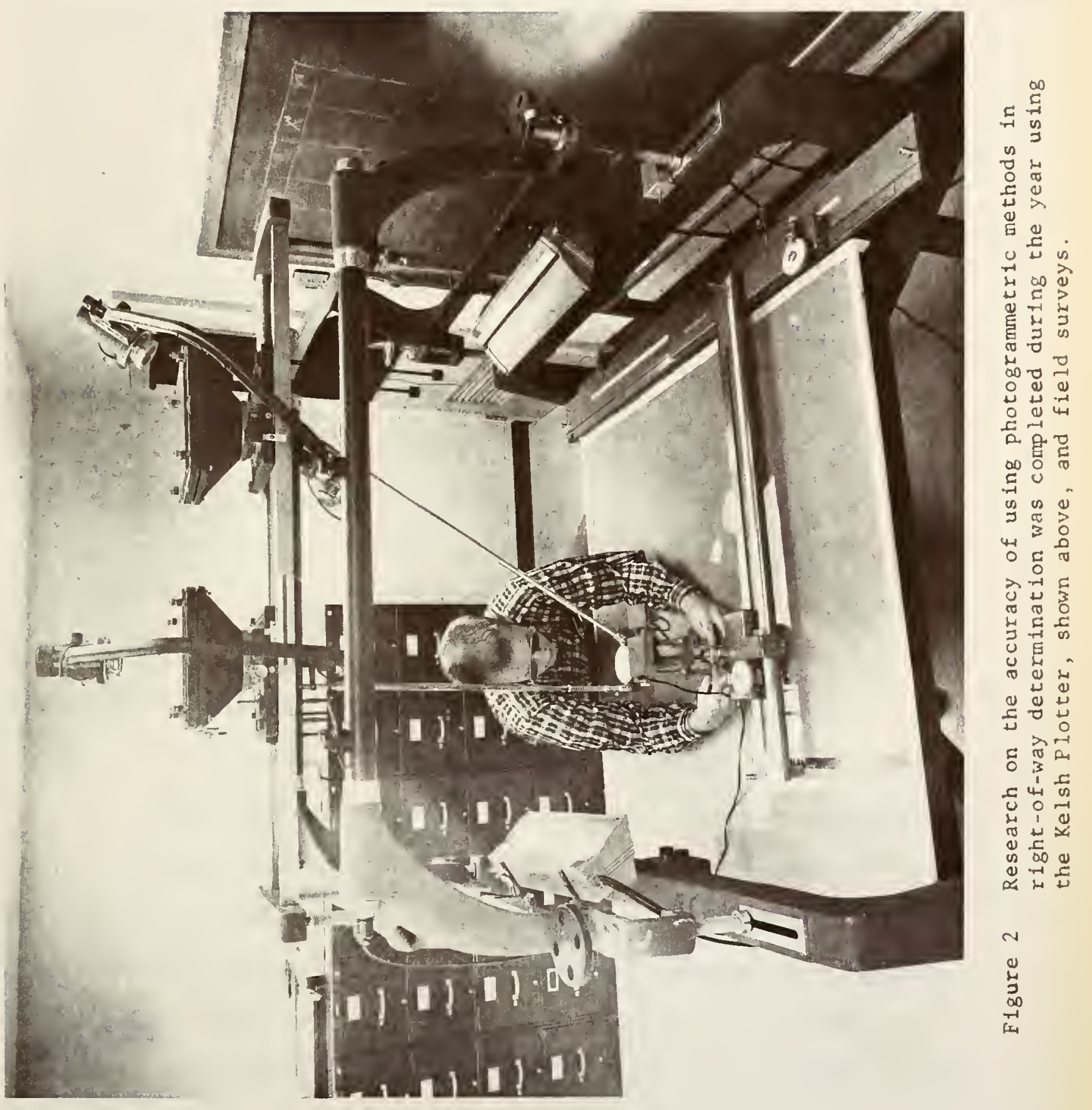


of soils. The goal, of course, is to minimize the amount of fleld exploration required for deslgn purposes.

Research in airphotos also Includes a study of the characteristics of watersheds which affect the runoff characterlstics. The purpose of the research is to determine how aerial photos cen be usad to evaluate these affecting characteristics so as to determine the runooff constants in a watershed area for highway structure design.

FInally research in the alrohoto area was just completed on the accuracy of using photogrametric methods in right-of-way determination. The results of photogrammetric surveys were compared with conventional surveying methods for right-of-way purchases and were found to be adequate as well as faster and more economical.

Bituminous Materials and Flexible Pzvements.

In a second area, bituminous materials and flexible pavements, major effort has been expended for many yaars in seeking a fundamental undersianding of bituminous mixture stability and durability and their measurement by laboratory tests. One current project is directed at evaluating the stress-gtrain relationships in bituminous concrete under 10ad. This information is of particular importance with the expanding use of bituminous mixtures in the lower lavers of pevements where $1 t$ distributes the load. A second project in this area is investigating the stmctural behavior of a mittwlaver nexible pavement under repeated traffic losis. Hopefully tinis research will permit a more accurate quantitative description of mixture parameters then present design methods provide.

Of continuing interest and study in the bituminous area is the skid 


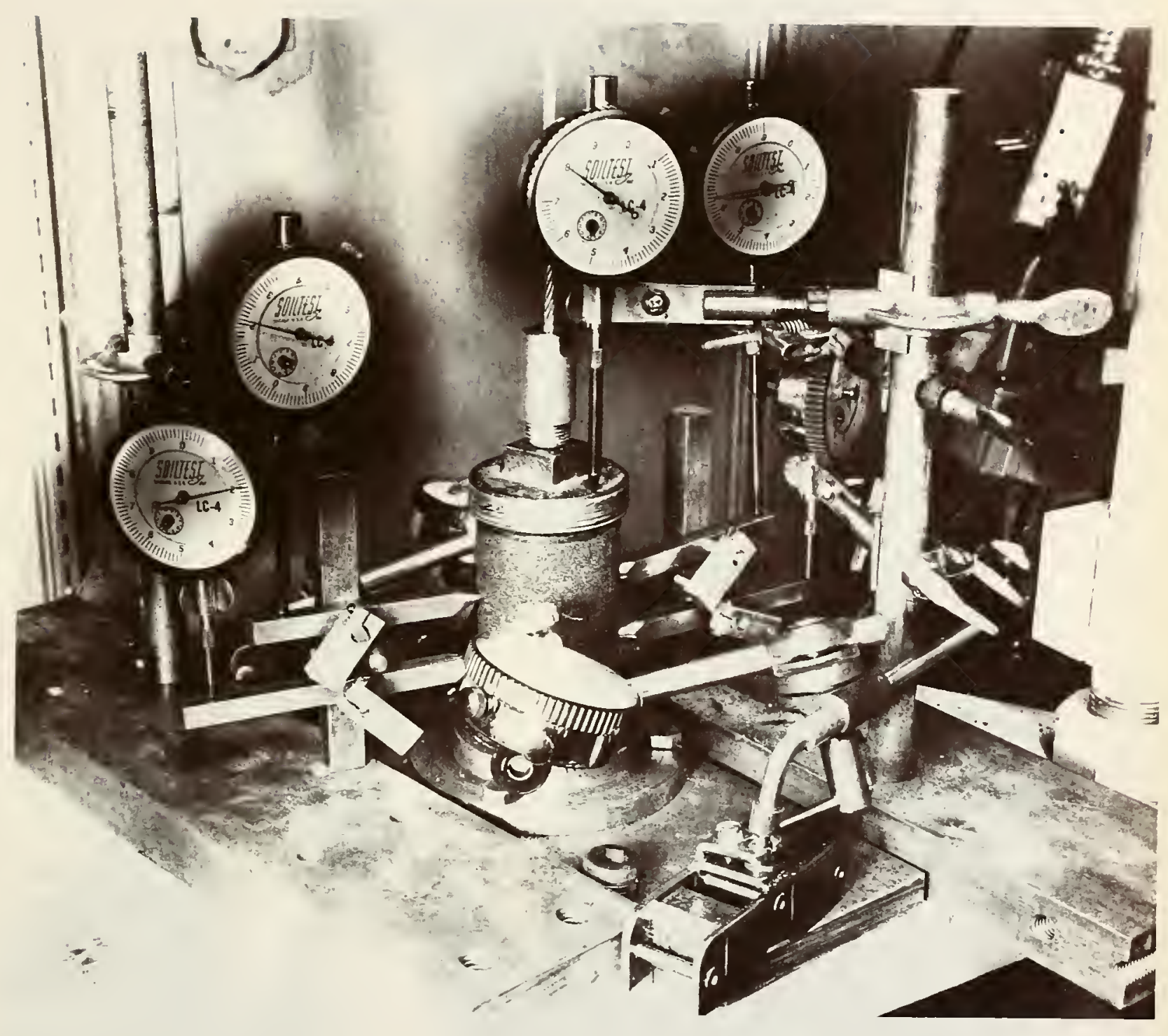

Figure 3 A uniaxial tension test in progress in the photograph above was taken during research on the two dimensional stress-strain relationships of a fine aggregate-asphalt system. 


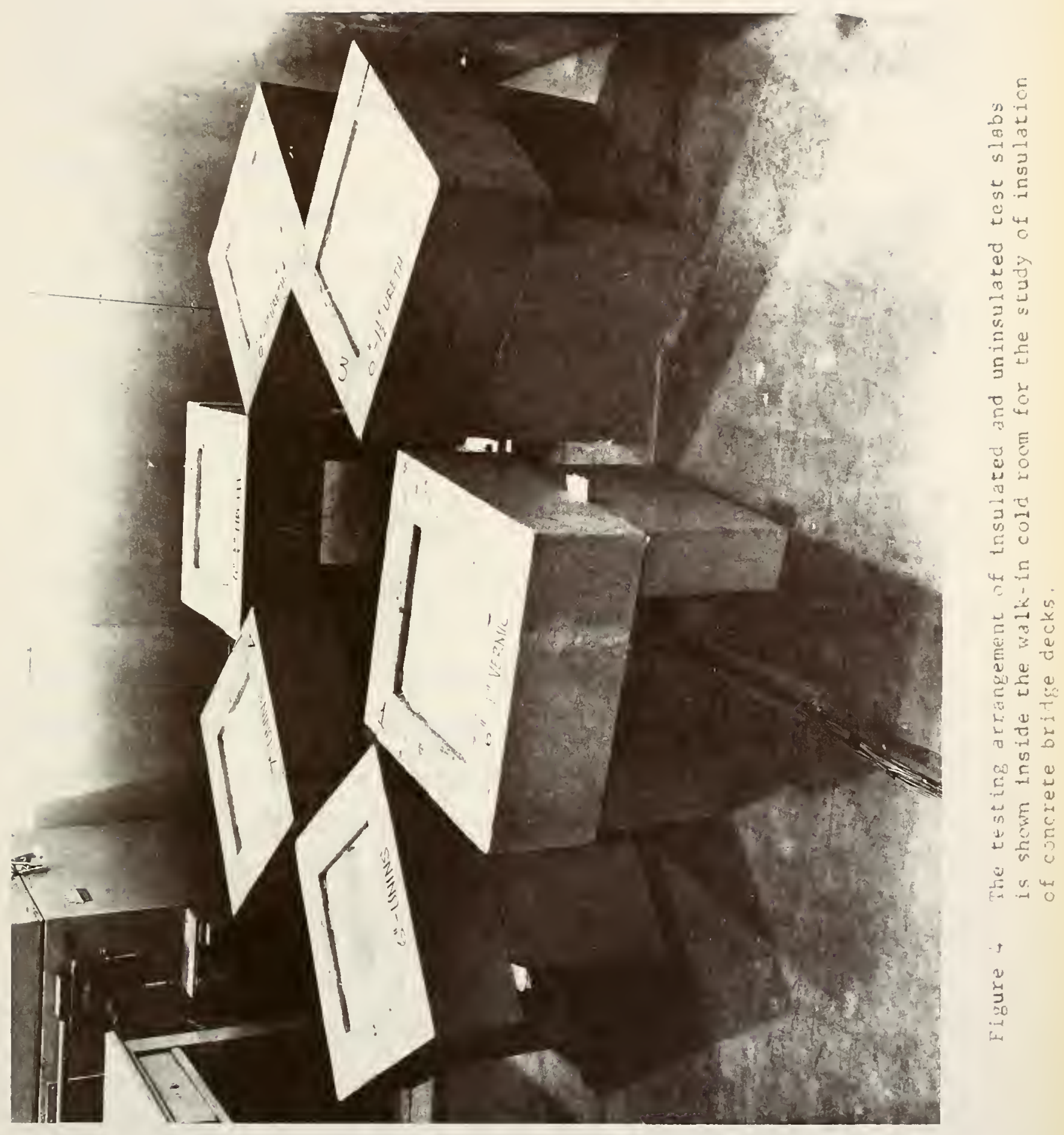


characteristics of pavement surfaces. Perfodic measurements are made of these characterlstics on existing pavements and on special test sections. Included is a study of the polishing characteristics of aggregates and the development of a IIne bituminous mixture with high slcia resistence characteristics.

Chemistry of Materials.

In the area of chemistry of materials, one current research project is concerned with volume change in concrete, a problem suggested as an Item of research at a meeting of the Board in Indtanapolts at Conmission offices, The purpose of this research is to investigate the influence of composition and tempcrature on the rate of volume change of concrete incorporating expensive cements. A better understanding of the nature of the expansive phase rill permit a better uililization of the proper cement in aintenance and construction applications.

A second project in this ares is directed at obtaining a better understanding and control of calcium silicate systems and portland cement. Observation and measurement of the properties of orthosilicates and their hydrates that are dependent upon the atomic, molecular and crystal structure of the orthosilicates is the goal of this fundamental study.

Another profect, recently completed, in this arca was a laboratsry Investigation of the effect of applying insulation to the understife of concrete slabs, such as on a bridge. Some clains bad been madr, that such application would minimize the freezing of vater on brfige decks, thereby minimizing the hazard of a bridge deck freezing b:forc its approaches. The research Indicated that such insulatici hod no affect 
on the temperature of the surface of tire slab and that such insulation rould be of little value in climinating this problem of the early freezing of bridge decles.

\section{Concrete Materials and Rigid Pavements}

One of the continuing projects in the concrete laboratory is the durablility of coarse aggregates in portiand cament concrete to freezethaw conditions. Basically this has consisted of an evaluation of those constituents in gravel and stone that are detrimental to concrete under conditions of freezing and thawing. Although much of this work was completed many years ago here at the Project, periodic durabilitiy tests are rade as requested by the Highway Comonission on aggreggte from new sources of gravel and stone.

Throughout the history of the Project several performance surveys have been made of highway pavements and bridge surfaces at the request of the Highwy Comisaion to determine the causes of deterioration. Such \& survey completed in June 1964 of concrete bridge surfaces disclased some scaling and other deterioration on bridge decks, even though recentiy constructed. Further investigetion disclosed the variables of season of construction and low air content to be possible causes of the failurea.

Although adequate air content has been lonown for some time to be fmportant in the prevention of concrete deterioration, a foolcoproof way of Insuring adequate air entrainment has not been found. In this problem area, two studies are currentlit in progress. One of these is a fleld comparison betreen portions of a structure which utiltzea normel airmentrained concrete and other portions which used concrete 


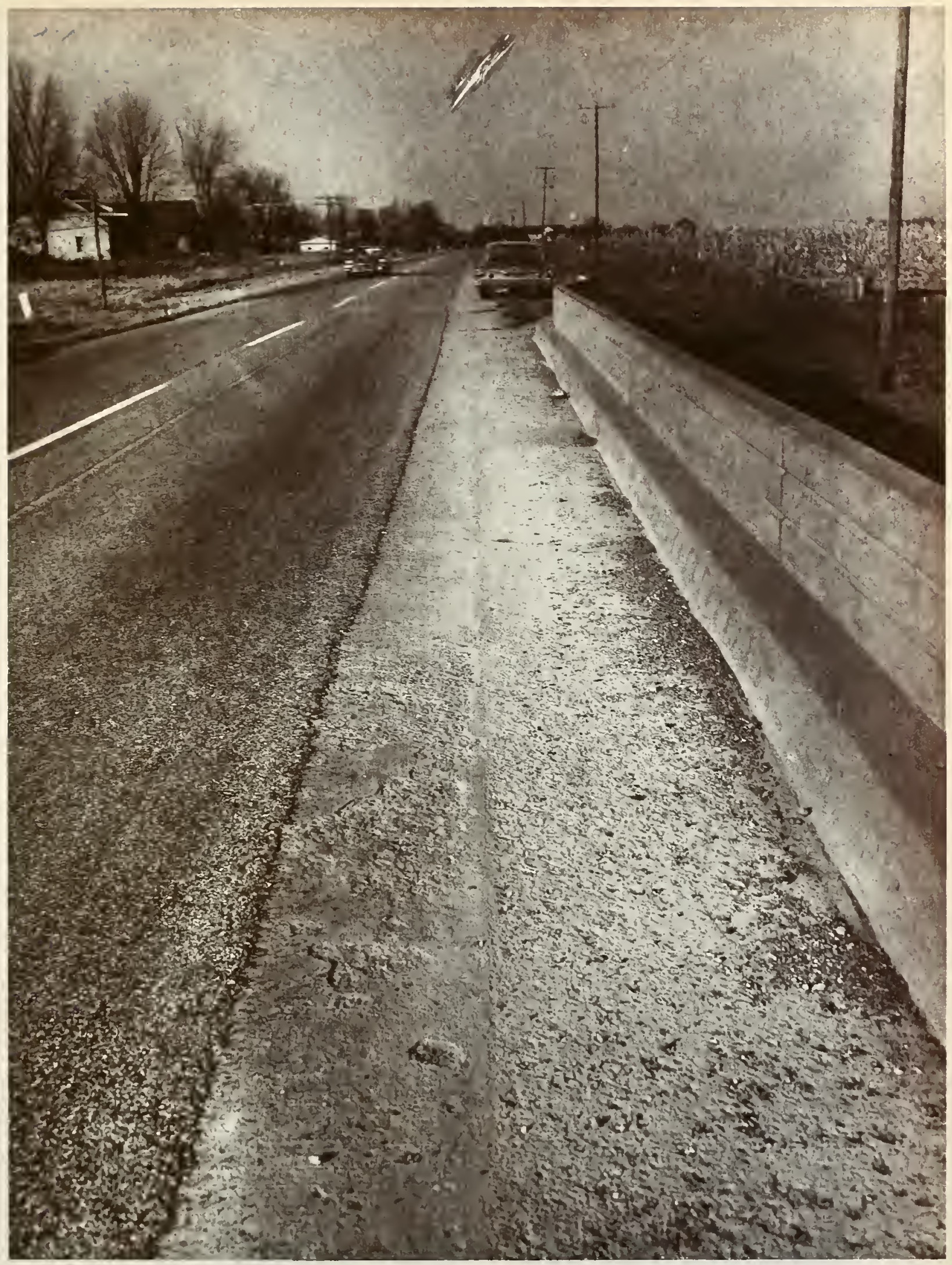

Figure 5 A bridge deck scaling survey in 1964 found some scaling and other deterioration on bridge surfaces of recent construction. The season of construction and low air content were indicated as possible causes of fallure. 


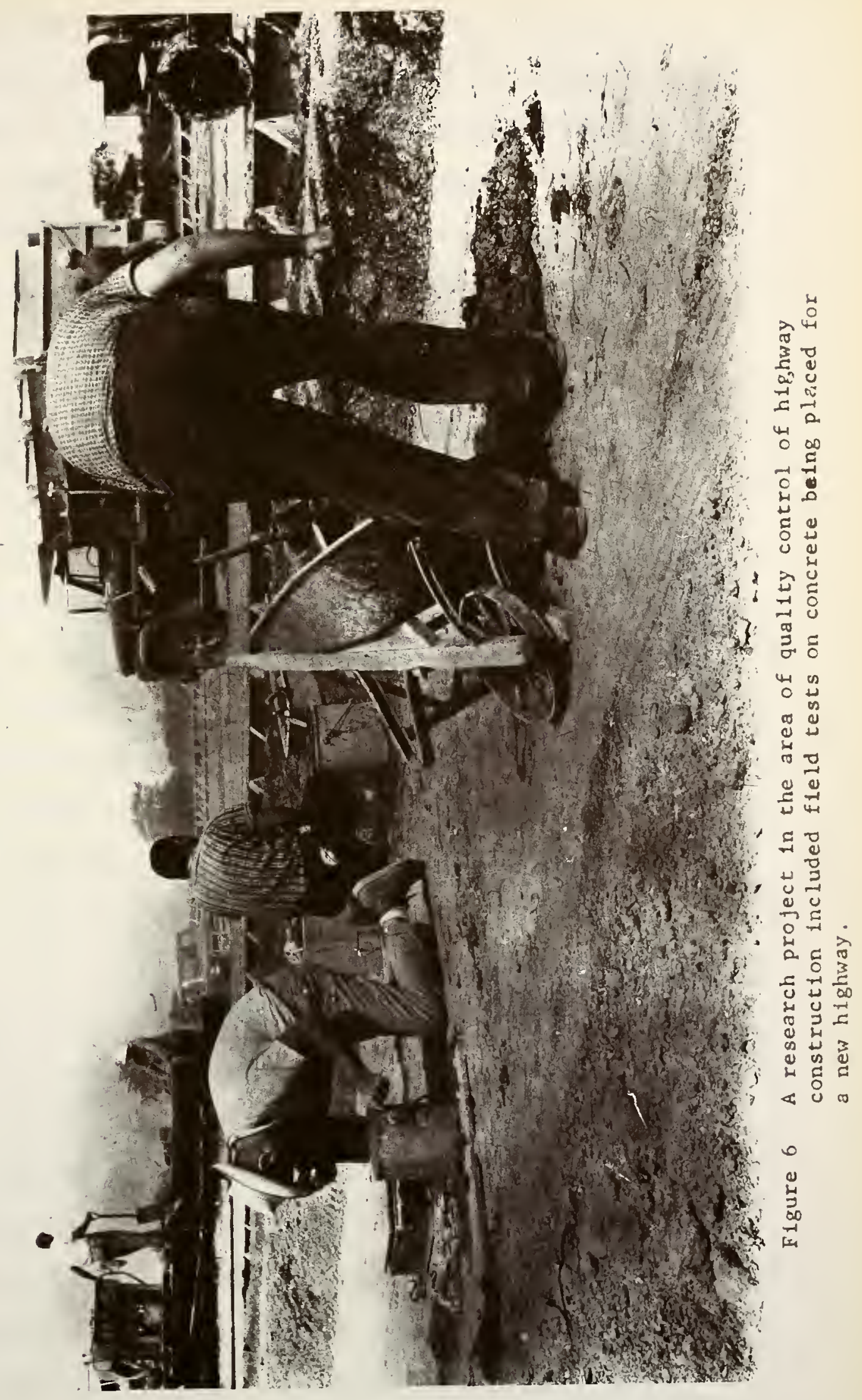


contalning a new additive which is clained to provide resistence to scaling and deterioration and wich is practical and foolproof to use. The reaults of this project, however, are not yet avallable.

A second project in this area was just instiated. The purpose of it is to investigate and determine the relationshlp between fIne aggregate gradation characterlstics and the amount of air entrained in a portiand cement stmcture. There is some indication that gradeo tron characteristics do influence air content and that proger gradation Inight be a technique which can be used to ingorove the alr content of portland cement concrete and its durability.

Other research in the concrete area is concerned with the examin. ation of existing theorles of pavement performance, the development of new theories, and the testing of these theorles utilizing the AASHO Road Test dete. The goal of this study is to develop a road performance hypothes1s which will permit extension of the Alsto Road Test results to other areas of the country.

Another project is a theoretical analysis of concrete alabs partialiy supported by the ground and subjected to moving loads and temperature variations. The results will be absessed in the light of existing theorles of slab performance and pavement deslgn.

FInolly this area is also conducting extensive research in the quality control area. The Itrat phase of the research was concerned with tests on plastic conrete produced for highway pavements. The second phese will be on the compaction of highway subgrades and bases. In this area, the Project is cooperating with nationowide Bureau research to obtain data on the quality of elements of the product of the highwy construction process. The result of all this research 
will be to encourage the use of a technique, statistical quality control, which will reasonably insure that a quality highway is being constructed at an econcrifeal cast.

Highway Economics

In the area of highway economics, research is active in the area of the lipact of highway fInprovements on traffic, land use, land value and comountty wellobeing. The impacts of six highway improvements o a rural Interstate highway, a major Iural highway without control of access, a controlled access bypass, and uncontrolled access bypass, a major urban frorovement, and the interchange area of two interstate highways near a large ucban area o are belng studied for short term and Iong term efiects. The econorates of controliting access, of constructing to four alane design, and of early purchase of rightwofway is inciuded. Other aspects of this broed study are the effect of highway Improvements on acciasnts, the epfect on traflic flow, the effect on amount and type of land use develonment and the effect on Iand values. Much important information has already been published from these studies and as the longoterm effects are evaluated, it is hoped that more inowledge on the total impact and ienefits of major bighway improvements will be learned.

A second study in this area has been devoted to what happens to those pieces of property wich remain when a part of the orfotnal plat is taken for a highwy richtwofoway. Of special importance here was an evaluation of the dsmages to the remaining property under conditions of land locking or seperation. One of the ltems investigated ras a compristing of the damges paid with the price obtained by omers fo: 


\section{0}

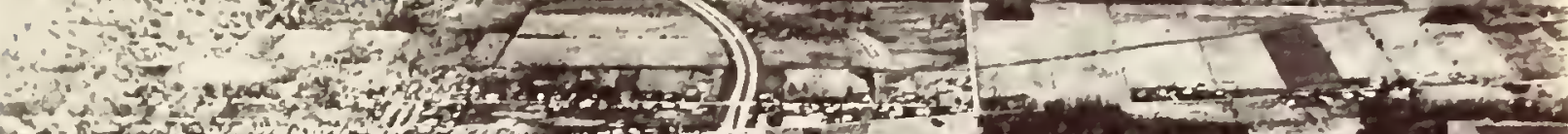

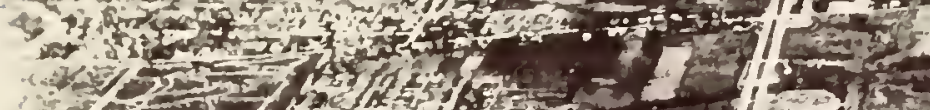

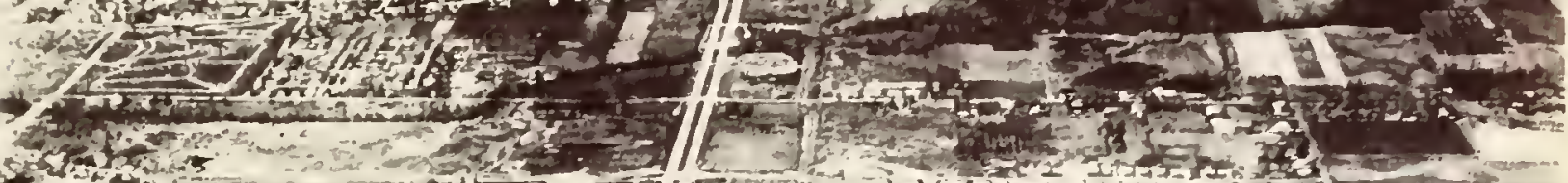

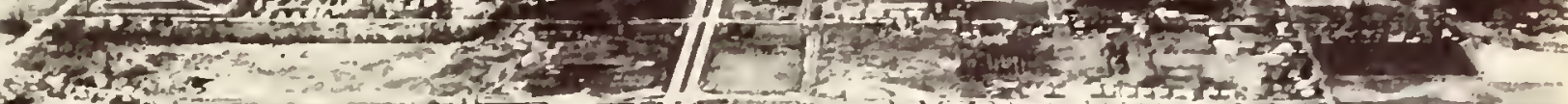

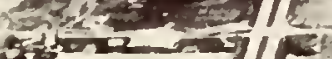

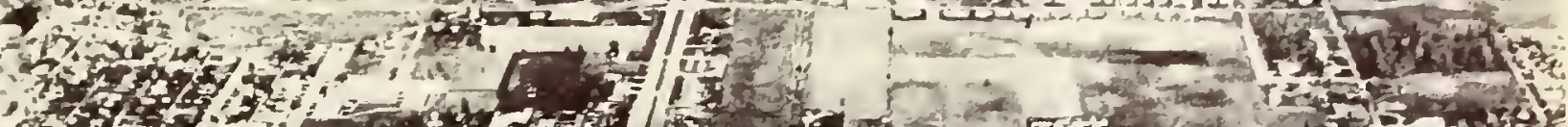

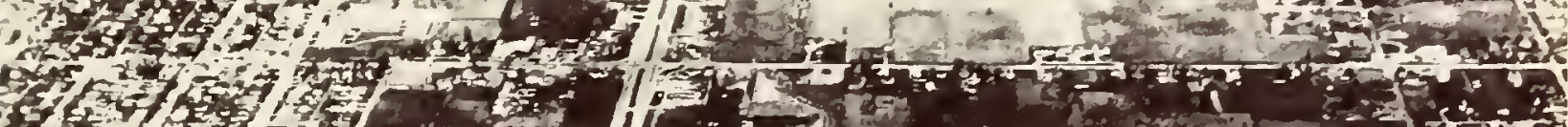

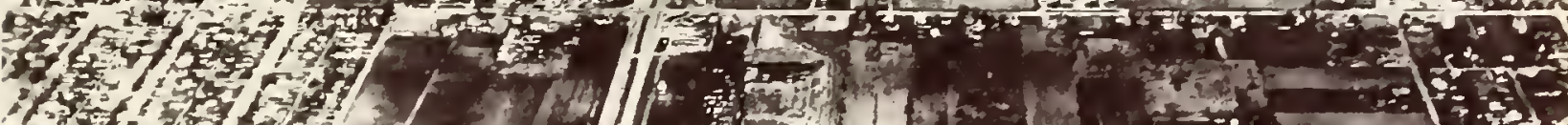

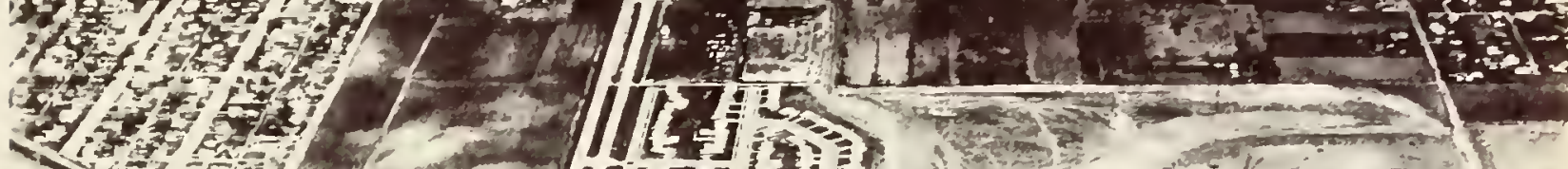

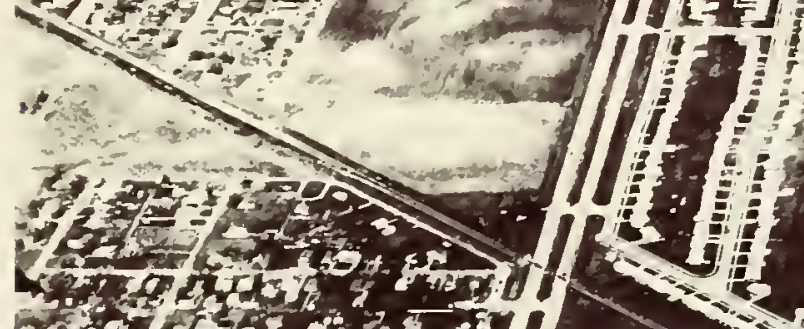

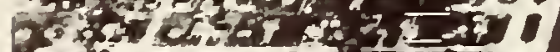

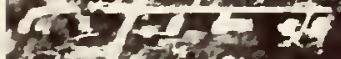

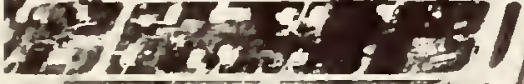
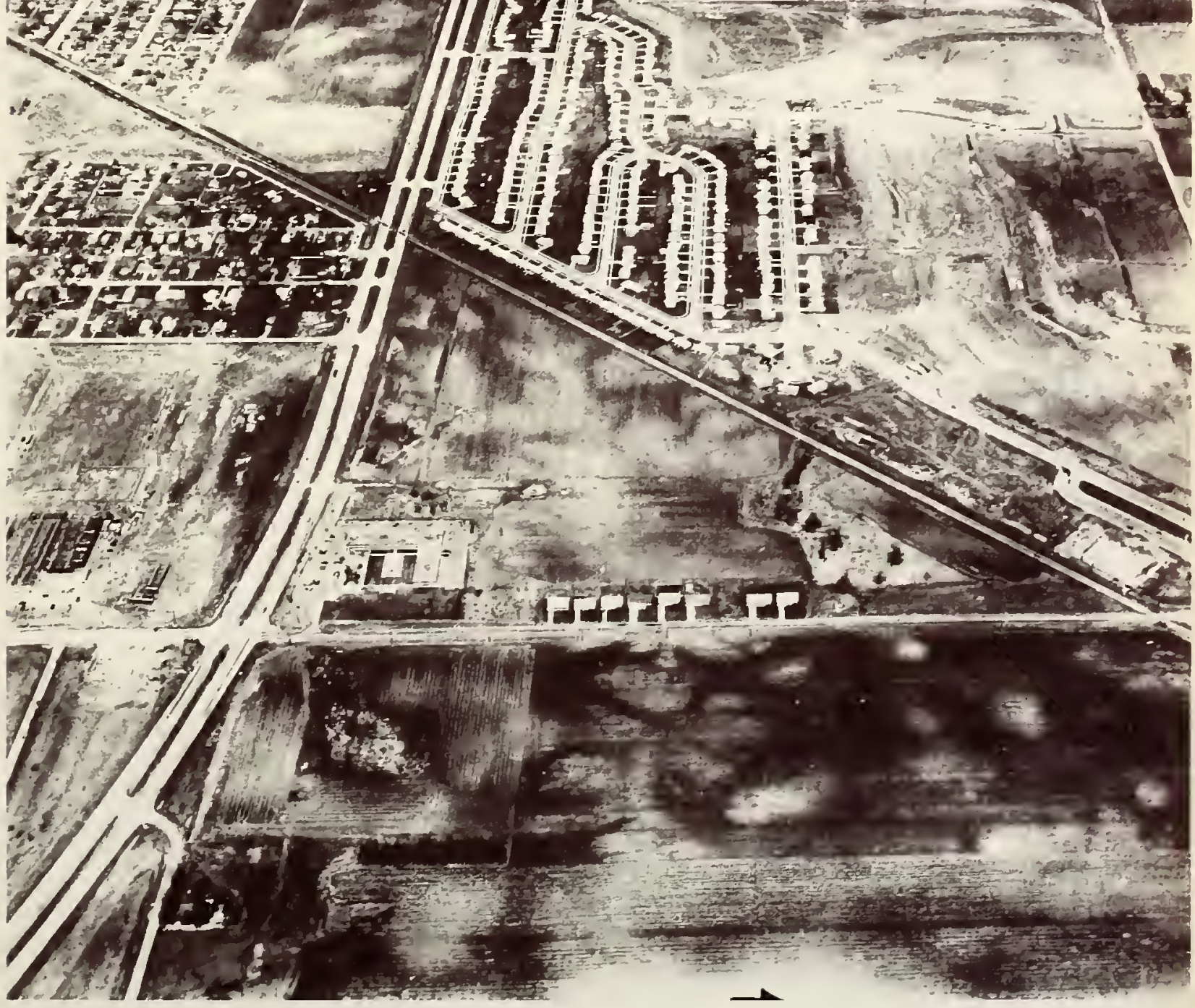

Figure 7 Highway impact research includes a long-term study of the effect of the Kokomo Bypass, pictured above, on traffic, land use, 1 and value and community well being. 


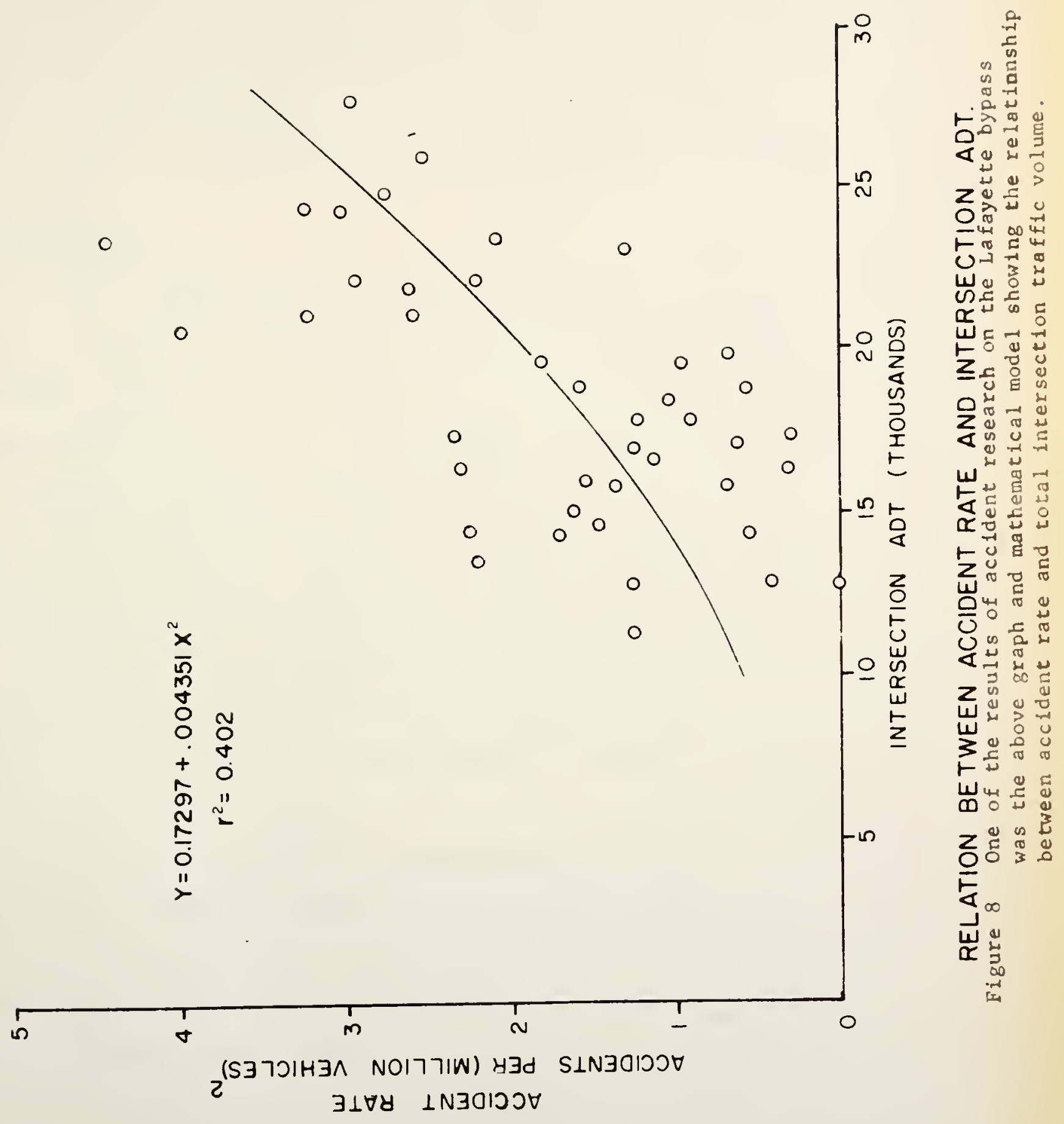




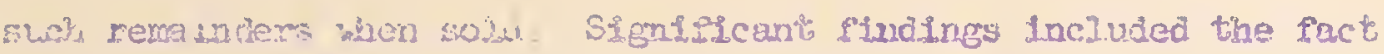
that more distages were being paid then actualiy susteined in a very

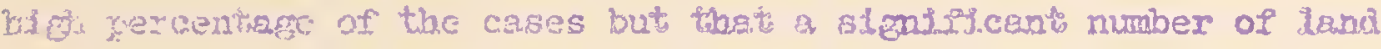
omej" tyere not receivin adequate reyment for the demeges recedved.

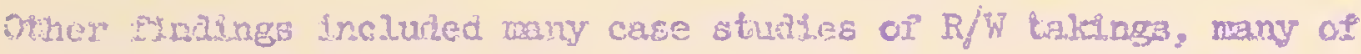

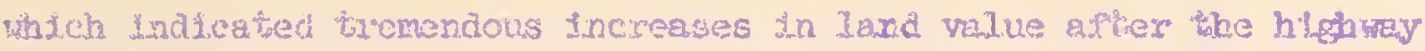
ingravenento

\section{Hif grway Safety}

With the steady incroabe in traffic acclaents und igtaluttes during tha pagt several grears, the Exajects has placed more exmasi.t. on satery research. Curreat ieserch in this area Includes a corprec

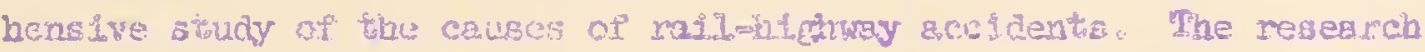

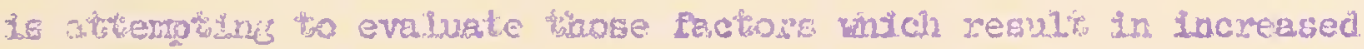

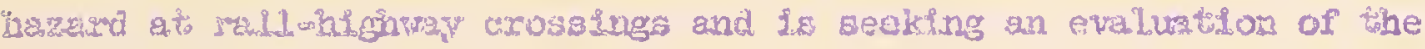
protectre value of the sevari types of ralliogd crossing warning and protective devices. To acidition, it is boped that a method cau be developed which will provide a resilfthe hanard rating for each crosslar in the atute 00 that adequate protective measures can be

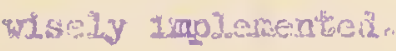

Another research project 1. concezned with accidents at the

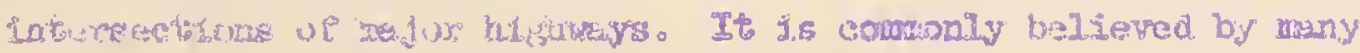

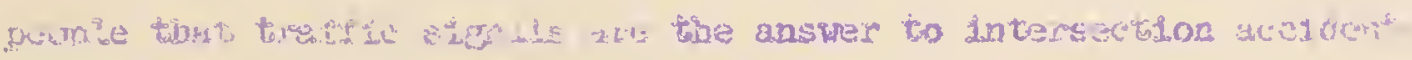

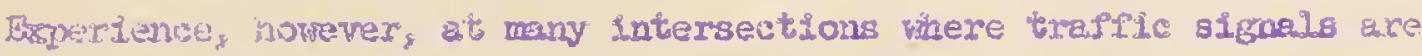
ingtilled indicates that accidents will Increese. This project is attemoing to evaluate the correlation between accident raten ana types w17 the iraffire sutrol \& intersections. The resulta ray provide

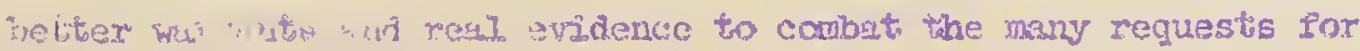


unwarranted traffic signals while at the same time juatiflying those that really wald reduce accidents sigatelcantiv.

A third project in this area is seeklng to Plad the urben design and system of traffle contral wiach will provide opilmum safety and movement on biftionvolume urban arterials. Horge of success in this recearch Ifes in the fact that some high volume urban arterials have

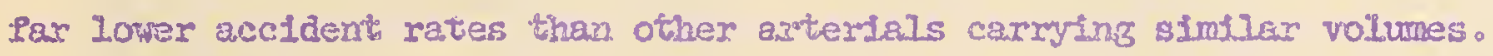
An evaluation of the reasons why this is true may produce lonowledge of great benefit in reducins traffic accidentso

Fing IIy, this area lis conducting a demonstration project on the U. S. 52 bygass at Lafayette to show the value of applying trafflc englaeerlat wo this hich acchdext, high volume artextal. This study Includes an evaluation of the causes of delay, the causes of accidentrs, recomendation for irproventents and evaluation of the ingrovernents. Includea also is the develojwent of a simutation andel wiah will duplicate the resulte obtalned frar the traffic enginexing changes on this bypass and which can then evaluate other posslble changes before they are made at this site and on other stmilar bypesses, of which we have severaj In Indiane.

\section{Solis and Paverient DeBfge}

In the area of scils and pavement design, a major project, its directed at developing Instrusentation sultable for megsuring acival sheel Loads of hlghway vehicles and the stresses and deflections Induced by these Ioads in the pavenent and subgrade. Swch moasurements vill permit realfstic evcluation of loadadeformation characteristics of pavements and the effect of varlous construction types, of operating gpecds and suriace condition. Such evaluation would peraft more econoalcal 


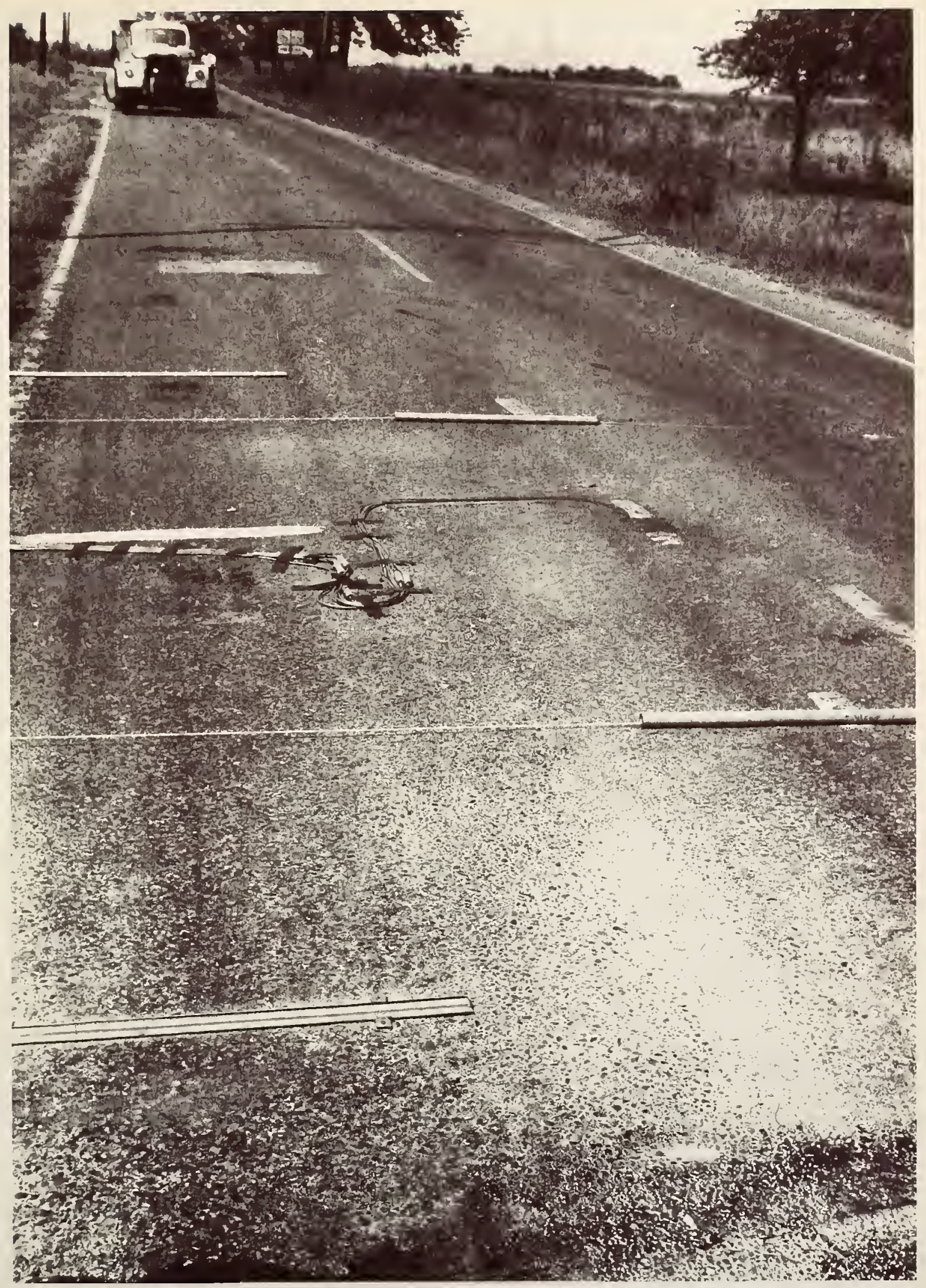

Flgure 9 The typical pavement test installation shown above was one site for the fleld lests on the research on pavement stresses due to moving loads. 
desiegs and the imposition of ilser controls and meintenance.

A second study 1s Linveatigating the strength pareneters of stabilized soll-aggregate mixtures to determine the type of sirength test that should be uscd to evsiuate Indiang aggregates wher stabllized with sare admiture A second phase of this reseercin deals whth the developrent of a design methor for such parententa so that snequate but exonomical Etaiolil\%ed pavements can be reliabiy designed.

\section{Trmanoortation Plan 3110}

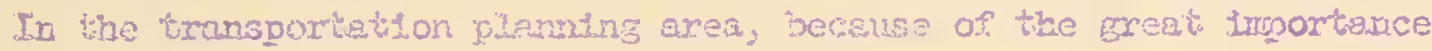
of urtan trundportation plansind ens the requirement thst every rajor

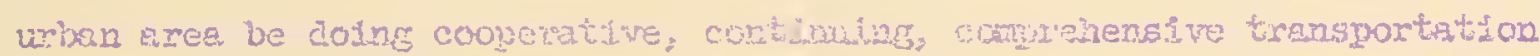

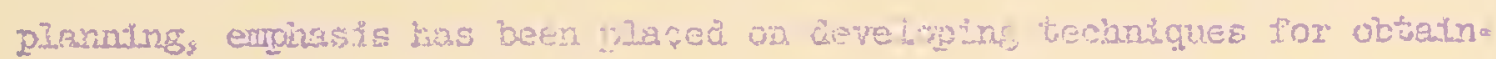
ung travel pativerns in an wizn wrae

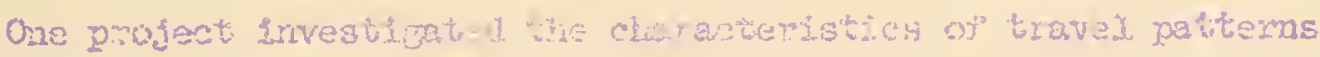
in sepers cLtes ars dete

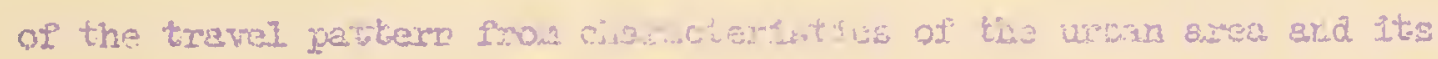

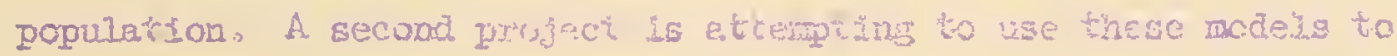

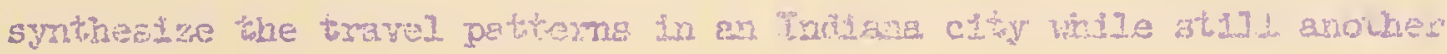
Is evaluatins the several up dating techrigues thet are avallable for travel pstheri ctudses. The purvose of these studies is to develom a tecinigue for obtaintuen the travel putterns for ar uxtbars area by a

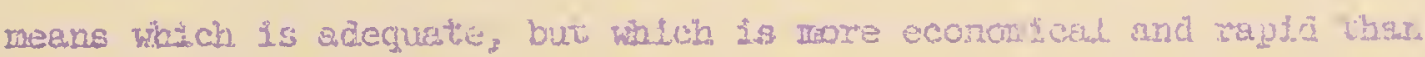

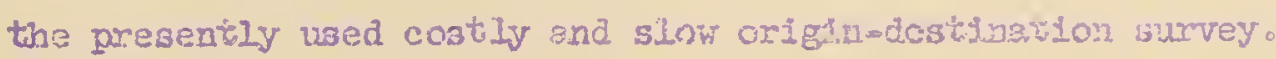

Another project in the planning aree is aivied at pormuleting e yalue function which w1.11 permit the assiguneirt of tripg to altararie rovites in a more realistic and accurgte Eannex then those tecrinigues currently used. The reason for tixe research is lihat present iechriques 


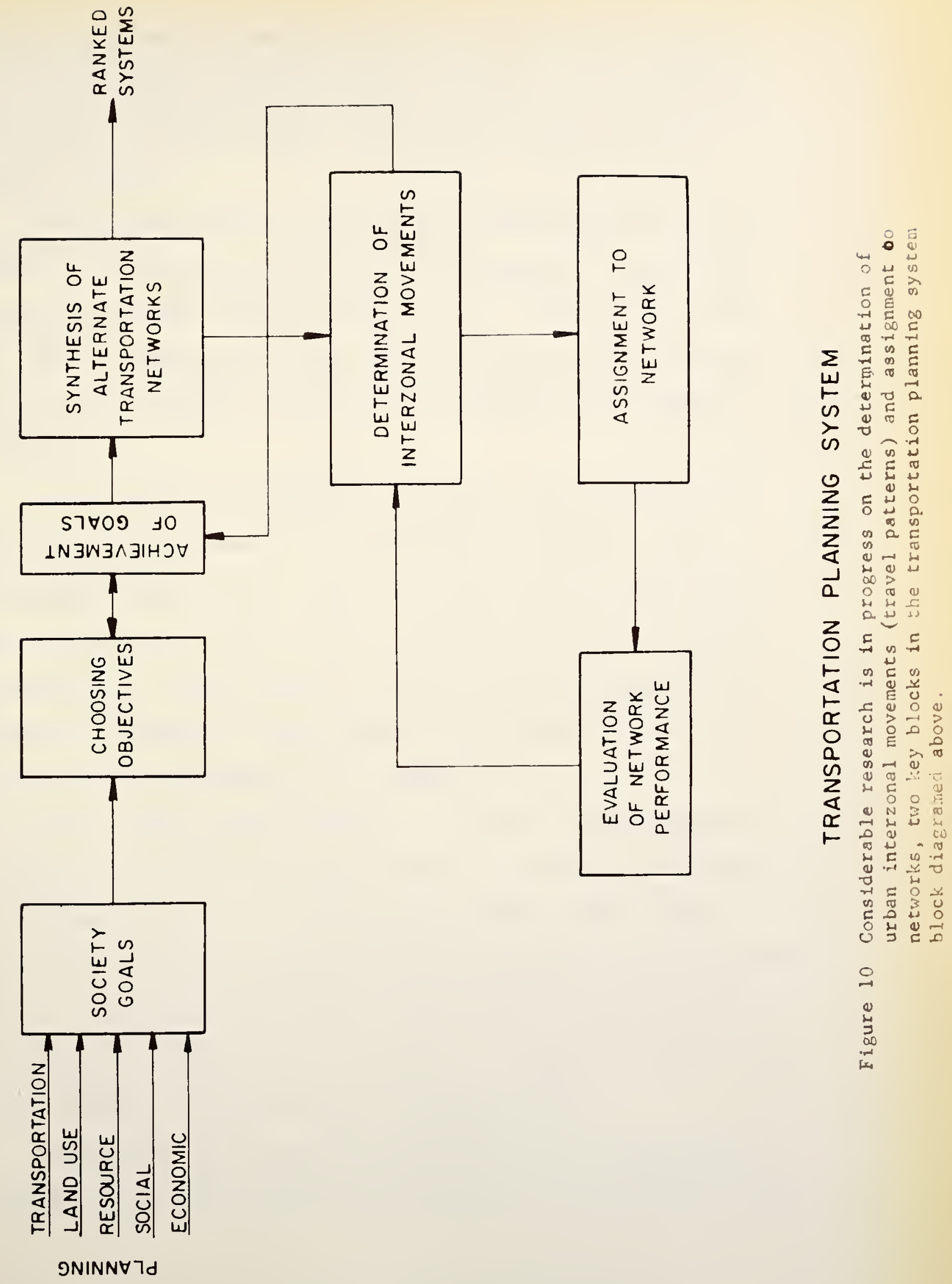


are beset with may problens and often groduce unrealigtic reauts.

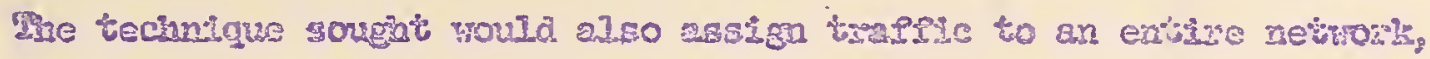

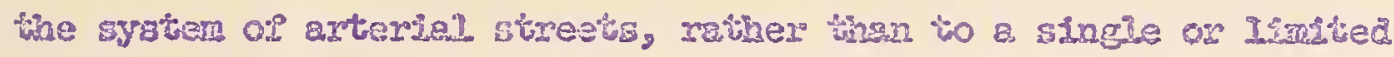
number of souries.

Other research in bih ares is concerned with reglona traved

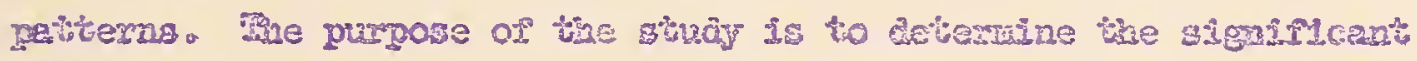

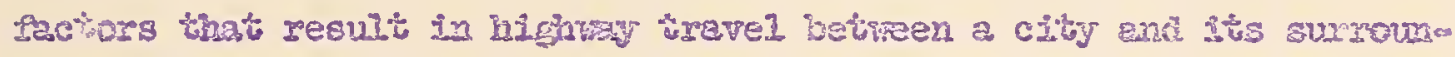
ding regicn. Perings the revulis Ning be of goeat value in reglons

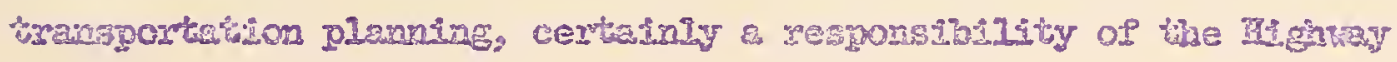
Comariston.

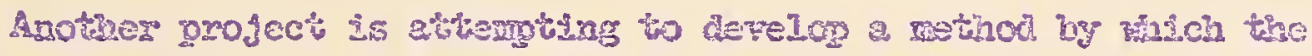

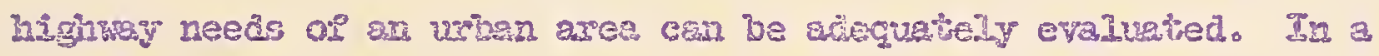

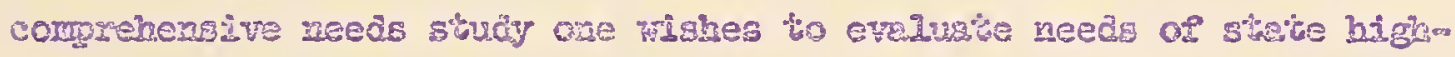
reys, courty rosds and chty atreets. The jatter because of the many

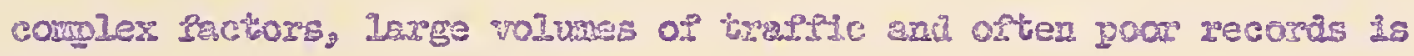

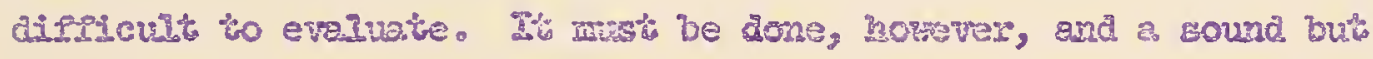
econorican and rapid mathod is being songth.

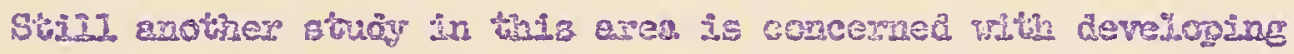

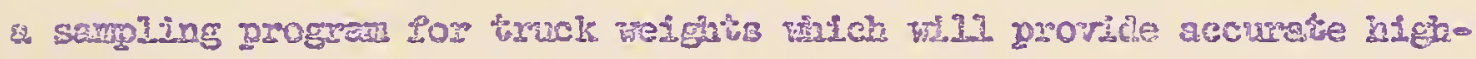

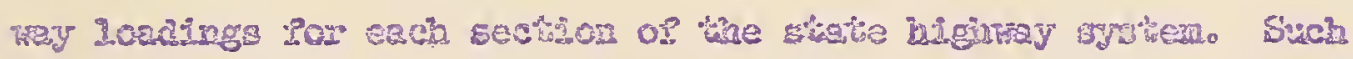
inporration or low

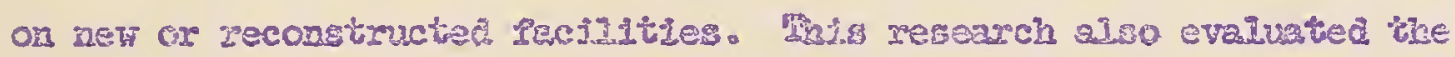

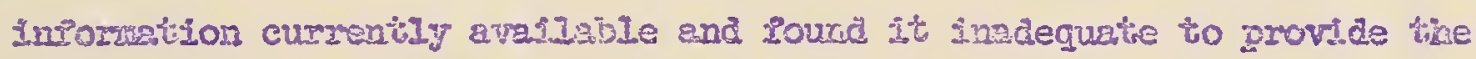
needed Indings for mogt secticas of the State Syrter.

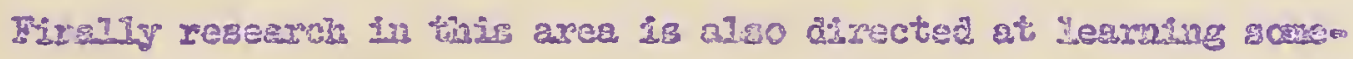

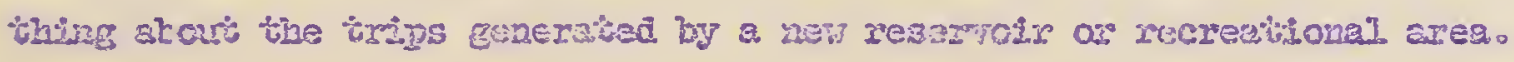


Op spectal interest is an evaluation of those factors ohich cause people to be attracted to auch areas so that better planning for tramportation and recreational facilfties can be performes for each such site, of which many are planned for the coniag yearg. Trapisic Eingtnearing

Research In trafflc engineering Includes ar evaluation of the benerits resuting from the instaIlation of a dersity controlled signal gyster in the downtown area of lafeyerte. The aftar conditions will be compared with tefore conajtions in an attemt to clevelop criterla Por installation of such systens in other cities.

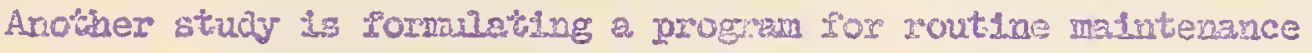

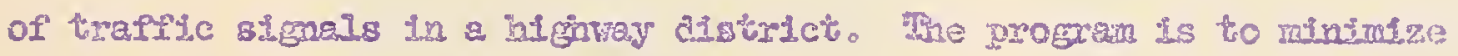
cost, hazard and maintenance cue to burnouts and other routine causea.

One gtuay ries a deternination of the tine gep required by motorists at stop ugas to cross a major btreet. Sich finformation Ls needed tor trafilc minulation programs axd is usefu? in developlag bether traptic

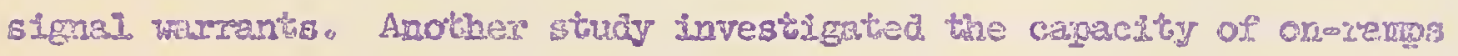

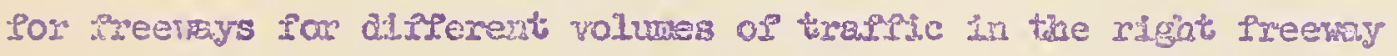
Iane. Tro other Etuaies, ane on greed trends and the other an the correlation betwen speed and mejght of trucks sre tread studies end have been in progress Pox runy Jears. Both of these studtes provice Information necessery for yogd destgn and glanoing of future inginkay as they provide a base for a realistic entimate of Puture speeds and future loads on inghreys.

A study was Juat inttlated to develop warrentis for the construction of refuge left turn lanes at signalized and non sLgnalized Intersectione 


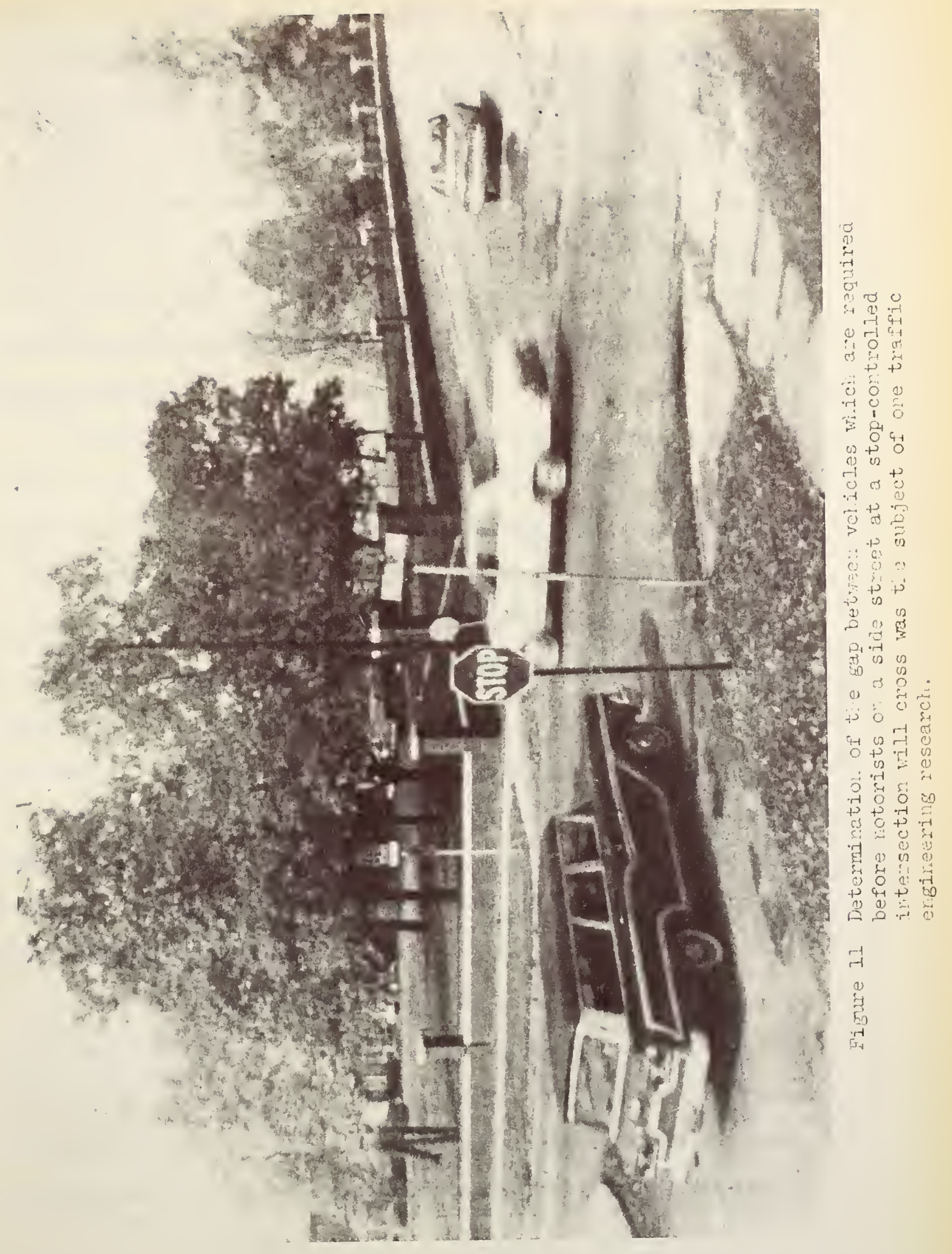


in rural and subsriban areas. The varrants will result from an evaluation of the costo of construction versas the valus of accideat reductions and reduced delays at Interasctong due to such left turn lanes.

Fimally a study is in progress co evaluate the cost to the scate of painting center Lines and edge lines with state personnel. Such information not only will provlde the gtate witb information useful In deciding on contract painting but will also permit thew to reduce costg by changes in methods which prove to be expensive.

\section{Spectal Brojectg}

In sddition to those projects already enumerated several apecial projects are in process. In the structurgl area a siudy was recenty completed on the creep and shrfukge characterlstes and the is effects on the canter in prestressed beans casts, cured and stored in the fleld. In the hydraulics aten a study of the runoff from swall drainage areas resuleed In a waul on peak discharge from gmall vatersheds in Indiano. Design hydrographs are included. The monual, extreaely useful to designers of drainage structures, is avsilable from the project.

A. study on the developrent of tests for predicting the anount and effect of aggregate degradation during handing and construction is in progress in the geology departant under the National Cooperative Raghray Research Program.

Lagtly, reserich has been in progress in the use of herbicides to obtain maximum reed control on roadsides. This stady also includes use of soil sterilants sround guard posts, bridge eads, etc. It is currenty Ey:-1ng exponded to include research in other roadside development areas the development of a better rosds wite tur $\bar{f}$, requiring less rasintenance 


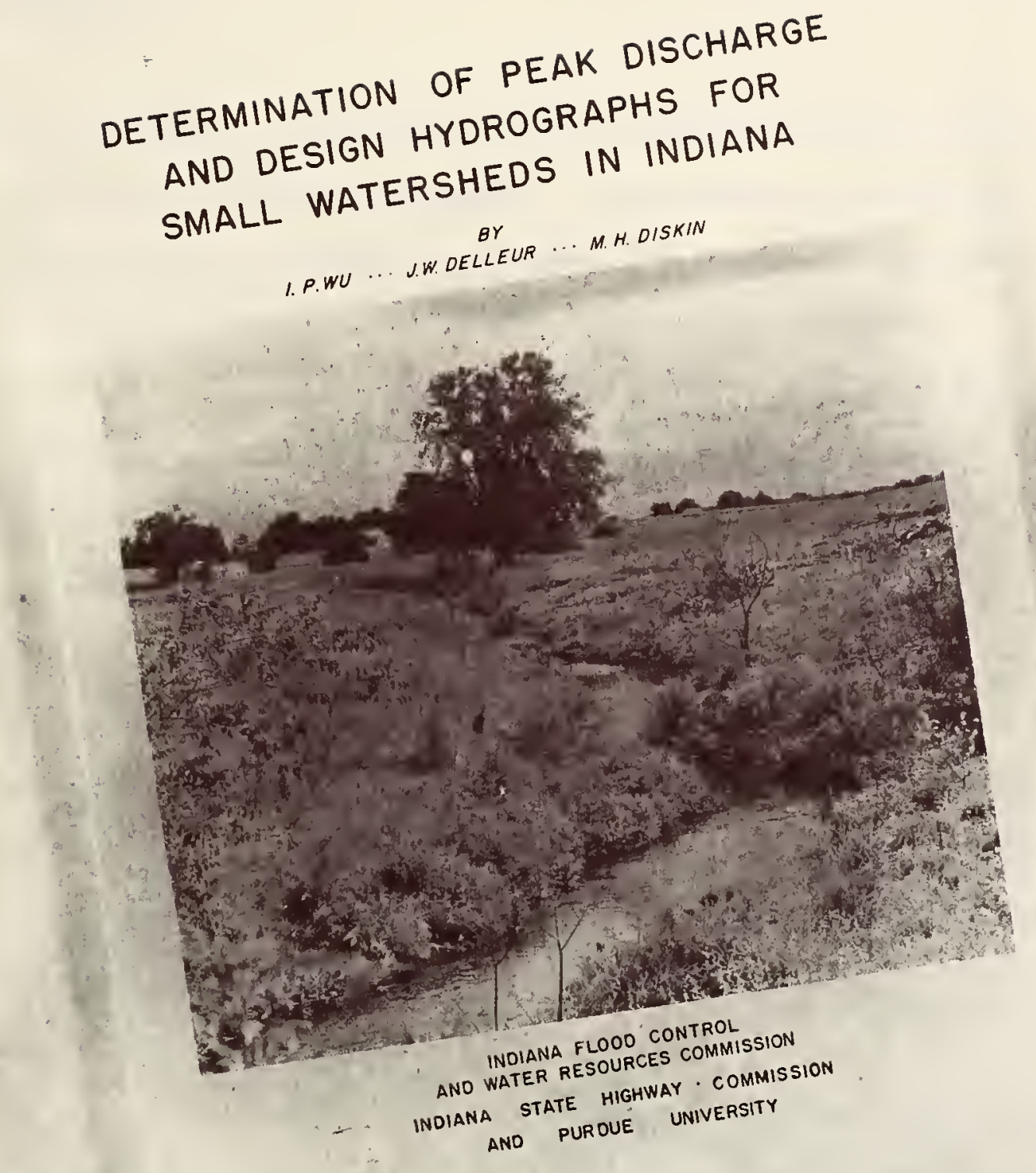

Figure 12 The product of one hydraulics study was the manual pictured above. The publication is avallable fxom the Joint Highway Research Project at $\$ 1$ per copy. 
and providing berter control of erosion, and the developwent of recomendations for the gelectlon, establishant and maintenance of suitable roadside plantings. Both of these are directed at improving the beaucy of the rosdbide while at the sams time minimiring the mintenance.

Sumarary

This brief resurse of the current highway research ot Burdue includes almost every area of bighway development. The projects are directed at real problems which are confronced by higbway persounel every day and which can provide useful Inforation toward the solution of these problews. There io much other research which could be done for there are wany problens yet unsolved. The Advisory Board and the staff, however, have atcempted to be selective and to authorize reseerch which is directed at important problems, for the actual value of research to the Mighway Comission degends, to a grent extent, on the Laportance of the problem to which the effort is assigned - that is, if the tffort is on trivial probleus, the rewards are apt to be trivial. Cercainly there is nothing trivial abost the problems of highway sceldents, zising maintenance cost8, deteriorating highways, traffic congestion and urban transportation planning. These are the type of problems ro which the current research is directed.

Somshow, however, there is always a lingering suspicion amang many that research is not redily an essential activity - that it could be reduced or even elfminated. Some, perhaps, are wondering abour the cost of the research described.

The current erpendture of state Highwy funds for project research is approxinately $\$ 250,000$ per year - $\$ 160,000$ from state funds plus 
$\$ 90,000$ of Rederal Aid funds administered by the state. Additional funds from industry, the federal government, the Bighway Research Board, the American Asrociation of State Highway Offlcials, national foundations, the Purdue Reseerch Foundation, the Highray Frtension and Research Project for Indiano Countes, and many other organizations and Irdividurls are aleo recelved annally for use in highay research and education at Purdue. These Eunds - which annully approzimate the total of etace highway funds - are also used for highwy research; the resulca of which are wade available to the Indisna Bighay Cowalsaion and which supplement the research financed by the Highway Cownission. The value of the building space and other itens of overhead contributed by che Untverstry to the operotion of the Project aust also be ircluded as part of the total finsucial picture of the project. The rotal annul cost of the Jolnt Highay Research Rroject is currently about $\$ 500,000$, including only $\$ 250,000$ of state highway adwinlstered funds. As the total product of chis effort is made avallable to the Indiana righway Coranaston this is a real bargatr for the state.

But the highway research progirms of each of the several stated, Including Indians, curt be Increased, for in the words of D. Grant Mickle, Eormerly Depury Federal HIghway Administrator and now Executve Director of the Highway Research Board, "Highwey offlelals are confronted with increasingiy complex problems of both technology end adminlstration. It is evident that improved and new techrologies, and methods of assimilating them into the Highvay transportation system, must be researched and developed."

And Robert F. Baker, Director of Research and Developwent of the Hureas of Public Roads has sald "I belleve strongly that highas transport- 
ation problems cannot be solved wichout the active support and particlpaton of universities. It is not enough that a university is interested in research work or even is competent to solve an individual problem. It must have the ability to undertake projects that may last for a considerable perfod of tiae and bay be very costly.... o. know for a fect that good research can be achleved and graduate education can be ascisted at the same thre."

To meer this need for expanded research, the Indlana State Highray Combission has authorized the construction and developaen of a righway Comission Research and Tralning Cencer at McClure Research Park in West Lafayetce, Ind1ana. With unity of purpose and the asarance of contiaued cooperation between the State Iighway Comisston and the Undversity, the staff of the Jolnt Highway Research Project looks forward to contlaued, coordinated, and expanded research on the many difficult problens which are present now and which unquestionably lie aherd. 

